\title{
Specificity of muscle antibodies in sera from patients with myasthenia gravis and from immunized rabbits
}

\author{
JOHAN A. AARLI ${ }^{1}$, OLAV TØNDER, AND OTTO CLOSS \\ From the Department of Neurology and Broegelmann Research Laboratory for Microbiology, \\ Department of Microbiology, The Gade Institute, University of Bergen, Norway
}

SYNOPSIS Citric acid extracts (CAE) of human skeletal muscle were prepared. Myasthenia gravis sera giving high titres in indirect haemagglutination test with this antigen, were selected. Rabbit antisera to CAE were prepared. The specificity of the two types of muscle antibodies was compared. Both patient sera and the rabbit antisera gave positive reactions in serological tests for muscle antibodies, but a difference in serological specificity was found.

Sera from some patients with myasthenia gravis (MG) contain antibodies to striated muscle. In immunofluorescence tests, different patterns of staining are described: cross-striational (Strauss et al., 1960), sarcolemmal-subsarcolemmal (Aarli, 1972) and 'granular-mottled' (Cossio et al., 1973). The different staining patterns may reflect different antigens in the muscle tissue.

Antibodies to skeletal muscle can also be produced by immunization of animals with muscle tissue homogenates or fractions thereof. The reactivity of these antibodies in immunofluorescence tests is similar to that observed with sera of patients with myasthenia gravis (Goldstein and Whittingham, 1967; Namba et al., 1967).

Recent observations indicate that the muscle antibodies from immunized animals and from MG patients react with different antigens in skeletal muscle (Stroehmann et al., 1973). The prime purpose of the present study was therefore to compare the specificity of the two types of muscle antibodies in reaction with a purified extract of human skeletal muscle tissue containing antigenic material.

\section{METHODS}

TISSUE PREPARATIONS Normal human skeletal muscle, usually from the thigh, was obtained at the Department of Surgery. Muscle tissue from rabbits was taken from the hind leg of healthy, non-immun-

1 Address for correspondence: Johan A. Aarli, Department of Neurology, 5016 Haukeland sykehus, Norway. ized animals. Citric acid extract (CAE) of human skeletal muscle was prepared as described by Espinosa and Kaplan (1968). The CAE was lyophilized and employed as earlier (Aarli, 1972).

SERA AND SERUM FRACTIONS MG sera with high titres in the indirect haemagglutination test for muscle antibodies (Aarli, 1972) were selected. Normal human sera were obtained from healthy blood donors. Normal rabbit sera were obtained from healthy, non-immunized animals. Incomplete anti-D serum was kindly provided by Dr K. Halvorsen of the Blood Group Laboratory.

Antiserum specific for human IgG globulin was prepared by immunization of a rabbit with the animal's own red cells agglutinated by human gamma-globulin solution purchased from AB Kabi Stockholm, Sweden (Larsen and Tønder, 1969).

Goat antiserum to rabbit serum was produced as described by Proom (1943). Rabbit antiserum to CAE was produced by intravenous immunization of a rabbit with $2 \mathrm{ml}$ of a $50 \%$ suspension of the animal's own red cells, treated with tannic acid $(1: 60,000)$ and coated with CAE diluted $1: 20$. Five injections were given through three weeks and the first serum samples taken one week after the last injection.

Before use, all sera were heated at $56^{\circ} \mathrm{C}$ for 30 minutes (inactivation).

Fractionation of serum on Sephadex G-200 was performed according to Flodin and Killander (1962), using $0.05 \mathrm{M}$ trisbuffer, $\mathrm{pH} 8 \cdot 0$, containing $0 \cdot 146 \mathrm{M}$ $\mathrm{NaCl}$ and $0.02 \%$ sodium azide. Samples of $2 \mathrm{ml}$ serum were applied to a column $(400 \times 18 \mathrm{~mm})$. 
Fractions of $5 \mathrm{ml}$ were collected at a flow rate of approximately $20 \mathrm{ml} / \mathrm{hr}$. The protein distribution with the effluents was registered at $254 \mathrm{~nm}$ in an Uvicord absorptiometer (LKB-produkter AB, Stockholm, Sweden). The fractions were absorbed with tanned red cells and used in the indirect haemagglutination test.

INDIRECT HAEMAGgLUTINATION TEST (IHA) The test with red cells sensitized with CAE was performed as described earlier (Aarli, 1972), except that rabbit red cells were employed. The reciprocal of the highest serum dilution giving agglutination was recorded as the titre.

ANTIGLOBULIN CONSUMPTION TEST (AGCT) The test was performed using human or rabbit muscle tissue sediments. For detection of antibodies in human serum, the procedure described earlier was followed (Aarli and Tønder, 1970). For detection of muscle antibodies in rabbit antiserum, the following modification of the same technique was applied: $10 \mathrm{mg}$ of rabbit skeletal muscle tissue were used as antigen preparation. Goat antiserum to rabbit serum, diluted 1:32 was employed as antiserum. The titre of the goat antiserum against sensitized sheep red cells was 2048. A $1 \%$ suspension of sheep red cells sensitized with rabbit antiserum to sheep red cells, at a dilution two times higher than the agglutination titre, was used as indicator cells (SSB).

The consumption of antiglobulin serum recorded when using untreated tissue was designated basal consumption. When the tissue was treated with normal human serum, an increased consumption was obtained (normal consumption). With some MG sera, the consumption was four times or more greater than normal (pathological consumption). The consumption was recorded as the ratio between the titres before and after absorption.

IMMUNOFLUORESCENCE TESTS (IF) were performed mainly as earlier described (Aarli and Closs, 1972), but without Evans blue. For some experiments, paraffin-embedded ethanol-fixed sections were employed (Sainte-Marie, 1962). For inhibition experiments, the sections were incubated with serum for 20 minutes at $37^{\circ} \mathrm{C}$ and then washed in isotonic, phosphate-buffered saline, pH $7 \cdot 2$ (PBS) for $20 \mathrm{~min}$ utes with three changes of buffer.

\section{RESULTS}

DEMONSTRATION OF MUSCLE ANTIBODIES IN RABBIT ANTISERUM AND MG SERA

Indirect haemagglutination test (IHA) Rabbit antisera, normal (preimmune) serum, two MG sera and normal human sera were titrated against tanned rabbit red cells coated with CAE. Anti-? bodies to the CAE antigen were demonstrated ino high titres both in rabbit antiserum and in $\mathrm{MG}^{\mathrm{C}}$ sera (Table 1).

\section{TABLE 1}

INDIRECT HAEMAGGLUTINATION TEST USING RED CELLS SENSITIZED WITH CITRIC ACID EXTRACTS OF MUSCLE $\stackrel{\text { ? }}{+}$ TITRES OBTAINED WITH HUMAN AND RABBIT SERA

\begin{tabular}{|c|c|}
\hline Serum & Titre \\
\hline $\begin{array}{l}\text { Rabbit antiserum } \\
\text { Normal rabbit serum (pre-immune) } \\
\text { MG-12 } \\
\text { MG-13 } \\
\text { Normal human serum }\end{array}$ & $\begin{array}{r}32,000 \\
<8 \\
128,000 \\
4,096 \\
<8\end{array}$ \\
\hline
\end{tabular}

Antiglobulin consumption test (AGCT) The AGCT was performed with rabbit antisera normal (pre-immune) rabbit serum and $\mathrm{PBS}_{\mathrm{i}}^{\mathrm{N}}$ and with serum MG 12, normal human serumio and PBS, respectively. The results, as seen an Table 2, demonstrate the presence of antibod to muscle tissue both in MG serum and rabsit antiserum.

\section{TABLE 2}

AGCT: TITRES OF ANTISERA AFTER ABSORPTION Wif MUSCLE TISSUE SENSITIZED WITH RABBIT ANTISERUM J CAE/MG SERUM AND WITH NORMAL RABBIT/HUMAN SERUM

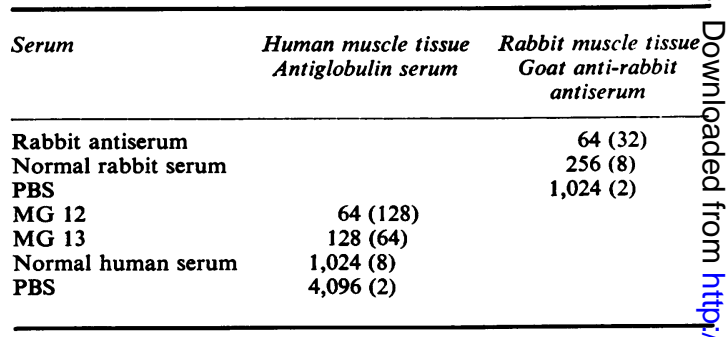

Antiglobulin consumption in parentheses, expressed as the ratio between titres before and after consumption.

Immunofluorescence (IF) tests IF patterns ob tained with rabbit antisera were mainly of sarco lemmal/subsarcolemmal type. With transverse sections of the tissue, a distinct staining of the periphery of the fibres appeared (Fig. 1). In longitudinal sections, both sarcolemmal/subo sarcolemmal staining and a variable degree of staining of cross-striations were demonstrated (Fig. 2). The same patterns were obtained wit\$ labelled $\mathrm{F}\left(\mathrm{ab}^{\prime}\right)_{2}$ - of IgG MG 12. Although smah 


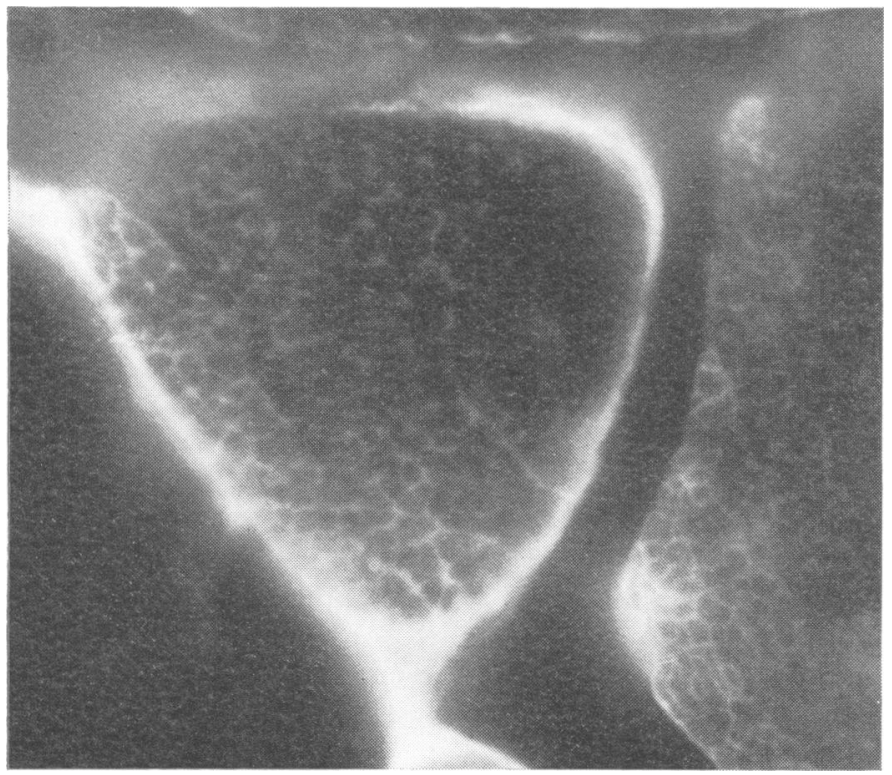

FIG. 1. Ethanol-fixed rabbit skeletal muscle incubated with FITC-labelled rabbit antiserum to $C A E$, diluted 1:16. Sarcolemmal fluorescence. Film: Ilford HP4, exposure time $40 \mathrm{~s}$.

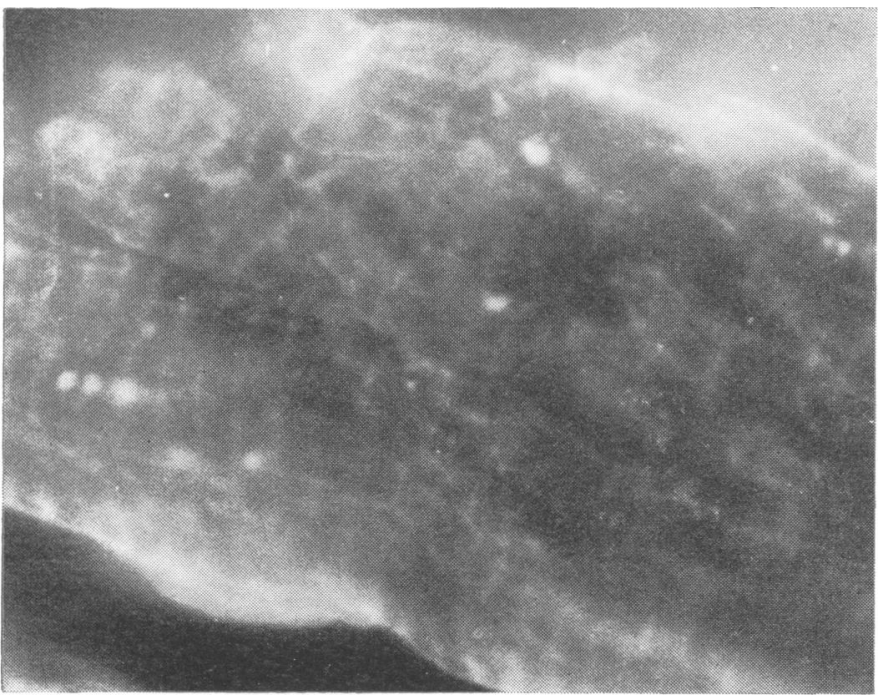

FIG. 2. Acetone-fixed rabbit skeletal muscle incubated with FITC-labelled rabbit antiserum to CAE. Crossstriational and sarcolemmal fluorescence. Film: Ilford HP4, exposure time $10 \mathrm{~s}$. 
differences could be seen in areas of the sections, these were of a quantitative nature, and the localization of the specific fluorescence was indistinguishable with the two sera.

NATURE OF ANTIBODIES In order to study which Ig class of the human and rabbit sera was responsible for the antibody activity against muscle tissue, serum MG 13 and rabbit antiserum were subjected to gel filtration on Sephadex G-200. The haemagglutination titres of the fractions were recorded. With the rabbit antiserum, fractions both from the first and the second protein peak agglutinated the cells. This indicates the presence of muscle antibodies both in the IgM and the IgG fractions. With MG serum, however, no agglutination occurred with the fractions from the ascending part of the first peak, while the fractions from the second peak agglutinated the cells, indicating mainly muscle antibodies of IgG type in this serumo (Fig. 3).

INHIBITION EXPERIMENTS EXperiments were peren formed in order to study whether the muscle antibodies of the two sera are directed agains the same antigenic determinant(s).

The antiglobulin consumption test was per $\overrightarrow{\overrightarrow{7}}$ formed with normal human serum and serumb MG 12. Before incubation with the tissue, the sediments were incubated for 30 minutes at $37^{\circ} \mathrm{C}$ with $2 \mathrm{ml}$ rabbit antiserum. Pre-treatment of the tissue with rabbit antiserum did not reduce the्e binding of human antibodies to the tissue $\overrightarrow{0}$ Corresponding experiments were performed with rabbit antiserum and muscle tissue presu treated with serum MG 12. The MG serum dief not interfere with the binding of rabbit anti흥 bodies to the tissue (Table 3 ).

Blocking experiments were also performedo with the direct IF test.'Sections of acetone-fixede

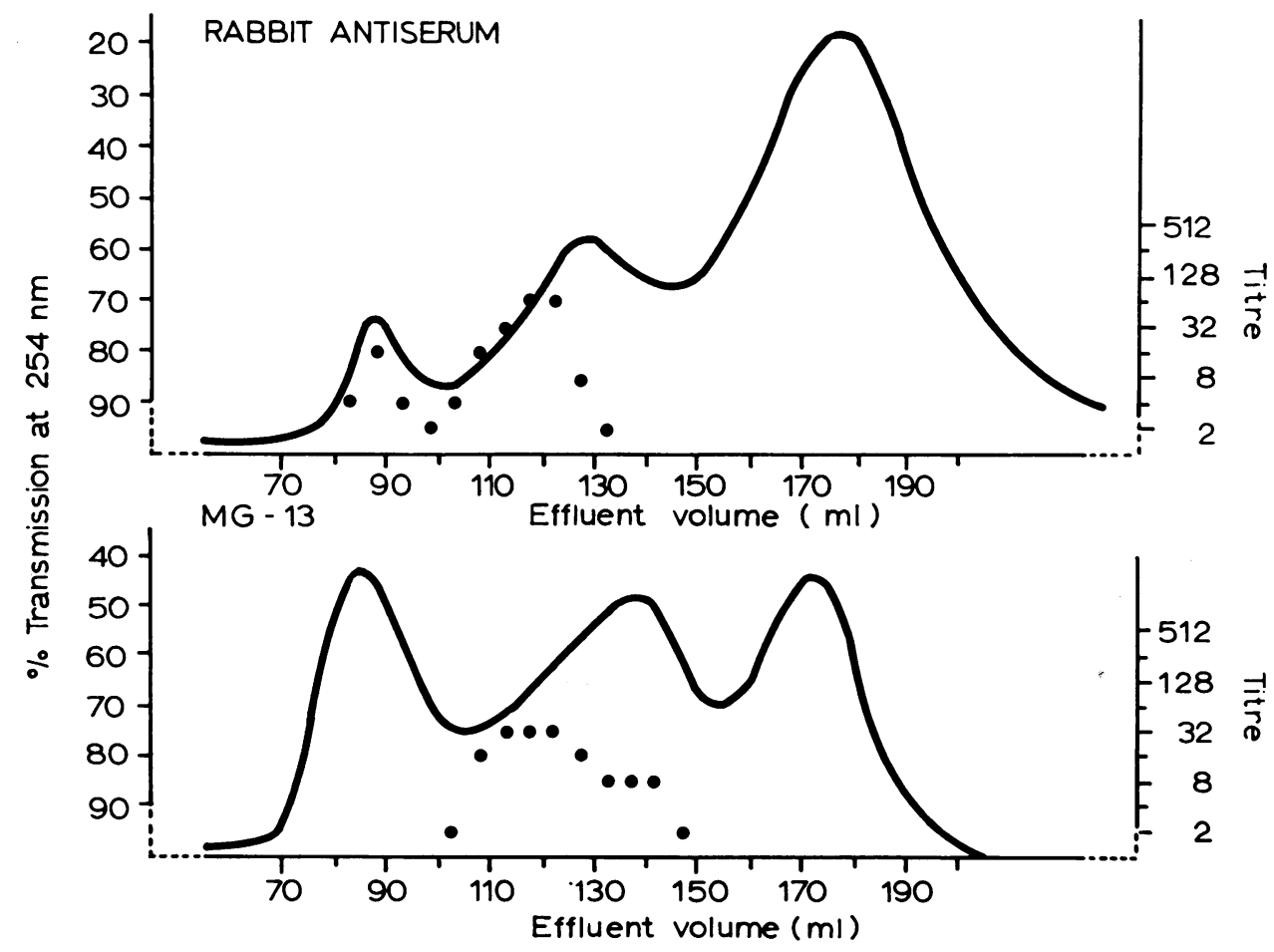

FIG. 3. Titres in indirect haemagglutination test with fractions obtained by gel filtration of rabbit antiserum to CAE (above) and serum MG 13 (below) on a Sephadex G-200 column. - Per cent transmission in effluents; $\bullet$ titres of fractions. 
TABLE 3

AGCT: EFFECT OF PRETREATMENT OF TISSUE WITH NORMAL SERUM, RABBIT ANTISERUM TO CAE AND MG SERUM

\begin{tabular}{llc}
\hline Pretreatment & \multicolumn{1}{c}{ Incubation with } & $\begin{array}{c}\text { Titre of } \\
\text { antiserum }\end{array}$ \\
\hline PBS & Normal human serum & $1,024(8)$ \\
Rabbit antiserum & Normal human serum & $1,024(8)$ \\
PBS & MG 12 & $64(128)$ \\
Rabbit antiserum & MG 12 & $64(128)$ \\
PBS & Normal rabbit serum & $256(8)$ \\
MG 12 & Normal rabbit serum & $256(8)$ \\
PBS & Rabbit antiserum & $64(32)$ \\
MG 12 & Rabbit antiserum & $64(32)$ \\
Rabbit antiserum & MG 12 & $64(32)$ \\
\hline
\end{tabular}

Antiglobulin consumption in parentheses, expressed as the ratio between titres before and after consumption.

rabbit skeletal muscle were incubated with PBS, normal human serum, rabbit antiserum, and serum MG 12, respectively. The sections were then washed three times in PBS and incubated with labelled MG 12 and rabbit antiserum, in different experiments. The rabbit antiserum did not block the reaction with the MG serum and vice versa (Table 4).

TABLE 4

IF TEST FOR MUSCLE ANTIBODIES: BLOCKING EXPERIMENTS

\begin{tabular}{lcc}
\hline Blocking with & \multicolumn{2}{c}{ Immunofluorescence } \\
& Rabbith \\
\cline { 2 - 3 } & Rantiserum & MG 12 \\
\hline PBS & + & + \\
$\begin{array}{l}\text { Normal rabbit serum } \\
\text { Normal human serum }\end{array}$ & + & + \\
Mabbit antiserum & - & + \\
\hline
\end{tabular}

\section{DISCUSSION}

Sera of some patients with myasthenia gravis contain antibodies to antigens present in acid extracts of skeletal muscle. Immunization of rabbits with such extracts results in production of muscle antibodies. The patient sera and the antisera both gave positive reactions in AGCT, IHA, and IF tests for muscle antibodies.

The antibody activity of the myasthenia gravis serum is mainly of IgG type. This is probably the result of a chronic antigenic stimulation, while the IgM antibody activity found in experimental antisera reflects the acute response of an active immunization.
The results of the inhibition experiments show that the rabbit antiserum does not block the binding of antibodies from myasthenia gravis sera to muscle tissue in the AGCT. Neither does pretreatment of the tissue with patient serum abolish the reaction with rabbit antiserum. In IF tests, pretreatment with rabbit antiserum did not interfere with the staining produced by labelled patient serum, as pretreatment with unlabelled patient serum did. On the basis of these experiments, it was concluded that the antibodies of myasthenia gravis sera react with different antigenic determinants than the experimentally produced antibodies.

Espinosa and Kaplan (1970) have demonstrated several antigens in CA extracts of heart muscle, partly cross-reacting also with skeletal muscle. The present data do not allow identification of the antigenic activity to a single component of the extracts. They are, however, comparable with those reported by Stroehmann et al. (1973), who found antibodies to 'the myosin complex of skeletal muscle' both in myasthenia gravis patients and in rabbits immunized with myosin-actomyosin-fractions. The IF patterns obtained were identical, with cross-striations as the dominating feature. Double diffusion tests revealed, however, that the antibodies were directed against different antigens of skeletal muscle. The CAE antigen gave very weak precipitation lines (Aarli, 1972), but other serological tests revealed, however, a difference in the antibody specificity with the two serum types.

None of the animals used for immunization developed clinical signs of muscular disease Similar findings are reported by other authors (for references, see Kaufman et al., 1969). The experimentally produced antibodies therefore seem to be of no pathogenetic significance.

This investigation was supported by The Norwegian Research Council for Science and the Humanities.

\section{REFERENCES}

Aarli, J. A. (1972). Myasthenia gravis. Antibodies to an acidsoluble antigen in striated muscle. Clinical and Experimental Immunology, 10, 453-461.

Aarli, J. A., and Closs, O. (1972). Myasthenia gravis: crossstriational fluorescence of muscle fibers mediated by $\mathrm{Fc}$ fragments. Journal of Immunology, 109, 271-274.

Aarli, J. A., and Tønder, O. (1970). Antiglobulin consumption test with sera from patients with myasthenia gravis. Clinical and Experimental Immunology, 7, 11-21. 
Cossio, P. M., Cornejo, L., Herrera, M., Vasquez, C., and Arana, R. M. (1973). Skeletal and heart muscle antibodies in myasthenia gravis. A new immunofluorescence pattern. Biomedicine, 19, 261-266.

Espinosa, E., and Kaplan, M. H. (1968). Antigenic analysis of human heart tissue. Identification of antigens with specificity restricted to heart and skeletal muscle in acid extracts of myocardium. Journal of Immunology, 100, 1020-1031.

Espinosa, E., and Kaplan, M. H. (1970). Antigenic analysis of human heart tissue. Antigens with restricted organ distribution in acid extracts of human myocardium. Journal of Immunology, 105, 416-425.

Flodin, P., and Killander, J. (1962). Fractionation of humanserum proteins by gel filtration. Biochimica et Biophysica Acta, 63, 403-410.

Goldstein, G., and Whittingham, S. (1967). Histological and serological features of experimental autoimmune thymitis in guinea-pigs. Clinical and Experimental Immunology, 2, 257-268.

Kaufman, B. M., Rushworth, G., and Wright, R. (1969). Experimental studies related to autoimmunity in myasthenia gravis. Journal of Neurology, Neurosurgery, and Psychiatry, 32, 281-289.

Larsen, B., and Tønder, O. (1969). Preparation of anti- human- $\gamma$-globulin sera not containing human serum proteins. Vox Sanguinis (Basel), 16, 69-72.

Namba, T., Himei, H., and Grob, D. (1967). Complement fixing and tissue binding serum globulins in patients witko myasthenia gravis, and their relation to muscle ribonucleo- $T$ protein. Journal of Laboratory and Clinical Medicine, 70, 258-272.

Proom, H. (1943). The preparation of precipitating sera for⿳亠二口犬 the identification of animal species. Journal of Pathology and Bacteriology, 55, 419-426.

Sainte-Marie, G. (1962). A paraffin embedding technique for studies employing immunofluorescence. Journal of Histochemistry and Cytochemistry, 10, 250-256.

Strauss, A. J. L., Seegal, B. C., Hsu, K. C., Burkholder,̄ P. M., Nastuk, W. L., and Osserman, K. E. (1960) Immunofluorescence demonstration of a muscle binding $\vec{\nabla}$ complement-fixing serum globulin fraction in myasthenia gravis. Proceedings of the Society for Experimentapi Biology and Medicine, 105, 184-191.

Stroehmann, I., Ricken, D., Naubereit, M., and Bruchhausen $\overrightarrow{0}$ D. (1973). Zur Immunpathogenese der Myasthenia gravis. Vergleich myasthenischer Skeletmuskelantikörper mi Kaninchen- und Rattenantikörpern nach Immunisierung mit Skeletmuskelproteinen. Research in Experimentat Medicine, 160, 181-195. 